Russian, Japanese, British, and Italian-Captain James never found his messages interfered with in any way. This notwithstanding that many of the messages sent were of considerable length, running from 1500 to 2000 words. To transmit these long messages under all the attendant difficulties was no mean achievement for wireless telegraphy and journalism alike.

Some of the incidents narrated by Captain James are both interesting and amusing. On one occasion, when the Japanese steamed in to attack Port Arthur, the Haimun telegraphed the news of the firing of the first shot to Wei-hai-wei, whence the message was forwarded express to London, with the result that two hours later the Times received the news, so that, on account of the difference in time, the journal knew that an engagement was taking place six hours before it started. On the occasion of the transmission of their first long message-one of 1500 words-which was sent from a distance of 130 miles from Wei-hai-wei, the operator listened anxiously at his telephone receiver, after the first section of 350 words had been transmitted, to know whether it had been satisfactorily received. For five minutes he waited; then his face lighted up, and he remarked, "Captain, we will deliver the goods, Wei-hai-wei says that it is coming in like a drum." It is a remarkable achievement, which journalists and men of science highly appreciate, that wireless telegraphy is capable even in adverse ci:cumstances of transmitting messages that will " come in like a drum." Wireless telegraphy may still be in its infancy, but the results attained by its use have shown that it is no longer in an experimental stage.

M. S.

\section{FLOODS IN THE UNITED STATES.}

I $\mathrm{N}$ our number for July 28 we gave particulars of the great flood that occurred in the Mississippi valley in 1903, and of the damage done in Kansas and other places, and also of floods in the Passaic River, the information being obtained from the reports issued by the Geological Department of the United States. We have revently received a further report on flocds in olher parts of the States. ${ }^{1}$

This report states that the vear 1003 will be lono rement-

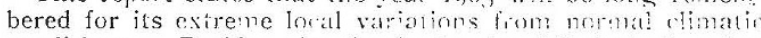
conditions. Besides the forrls in the Miss w mon vallos

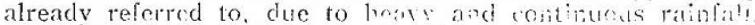
a cloudburst at Inppner, in Orgon, atuond the loss

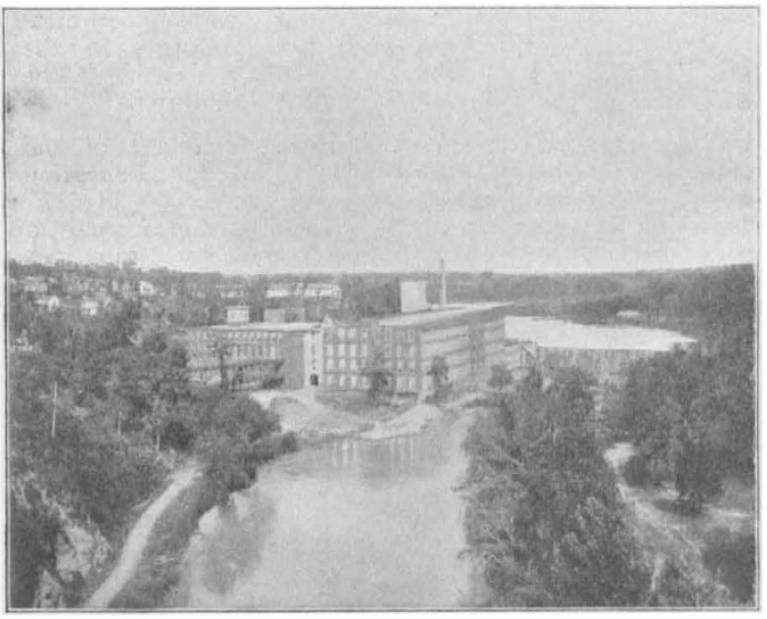

F1G. 1.-Cifiton before the Flood of 1903.

of roo lives and of property valued at half a million dollars, one-third of the town being entirely destroyed. This flood was due to a very heavy storm of short duration covering a very small area, such storms being peculiar to this arid region, and locally called a "cloud burst." Such a storm 1 " De:trucr,ve Floods in the $\mathrm{U}_{n}$ ted States in $x$ 703." By E. C. Murp.y. Water Supply and Irrigation Papers, No. 95. (Washingtun.)

NO. I 834 , VOL. 7 I 7 is almost like a tornado in its suddenness, destructibility, and limited extent. The duration of this storm was only half an hour, and the resulting flood lasted less than an hour. It. was estimated that the storm area twas from two to four miles in width and eight to ten miles in lerigth, and affected an area of twenty square miles.

This storm was accompanied by a very imar fatl of hail; some of the hallstones measured th in: ines ti dianeter.

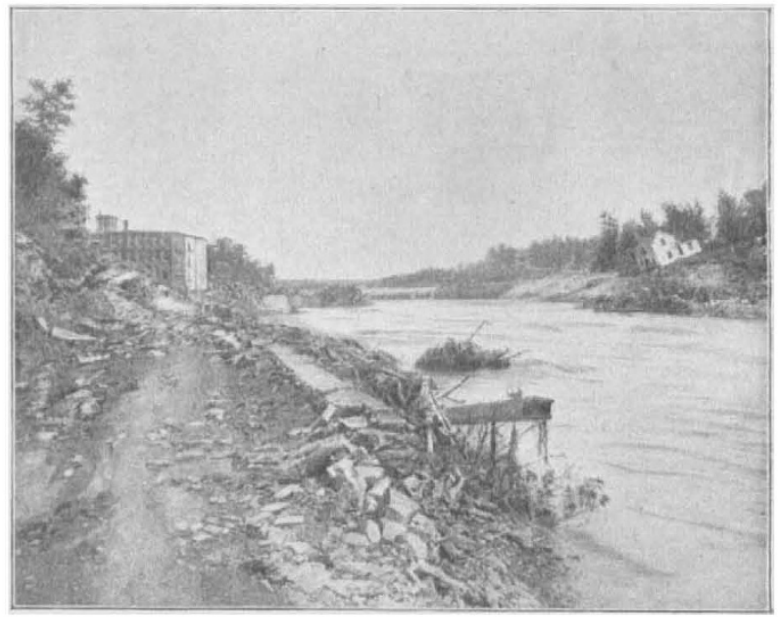

FIG. 2.-Clifton after the flood of 1903 .

Five days after the storm some that measured five-eighths by seven-sixteenths inch were removed from a house buried under silt and mud, and bodies were found in drifts of hail in nearly a perfect state of preservation.

Another destructive flood due to heavy rain occurred in Snuth Carolina in the district situated on the southern slope of the Saluda Mountains, which includes the foothills and rolling country. $\Lambda$ bout half of it is covered with timber, the remainder being cultivated and pasture land. The surface slopes are such that the water runs off rapidly, and there is very little storage.

Rain had occurred daily for some time previously, salurating the ground, and culminating in a fall of from $3 \frac{1}{1}$ to 5 inches in twenty-four hours.

The greatest destruction caused by the flood due to this rainfall was the wrecking of three large cotton mills situated at Clifton (Figs. 1 and 2), on the river Pacolet. At one mill a chimney stack 137 feet high was washed down, and the mill, with shops, engine and boiler houses. and sixteen cottages, entirely destroyed. At another mill I In feet of the main building and the wheelhouse were totally wrecked, and the machinery of the lower floors severely damaged by water, mud, and drift, and several cottages were destroyed. In another mill fifty-two women and children were drowned. Railway traffic ivas stopped for a week. The damage to the mills and other property was estimated at $3^{\frac{1}{2}}$ millions of dollars.

\section{SEISMOLOGICAL NOTES}

[HE third number of vol. $x$. of the Bolletino of the Italian Seismological Society contains the first instalment of the earthquake record for 1903. This is now in charge of Dr. G. Agamennone, and follows the same lines as in previous volumes, except that it has been found impossible to continue the attempt to reproduce all the records of earthquakes registered in Italy. This change is a consequence of the great increase in the number of stations where instruments devoted to the new seismology have been set up, and the consequent impracticability of collecting in one periodical all the records of even the limited number of great world-shaking earthquakes. Italy will, therefore, be content with publishing its own records, and at most a few lines will indicate those earthquakes which have also been recorded out of Italy. 
Improvements are continually being made in the instruments used in every branch of science, and seismology is no exception. Prof. Omori publishes (Publications of the Earthquake Investigation Committee, No. I8) an account of a combination of light, inverted, vertical, with a heavy horizontal pendulum, with which it is claimed that a period of sixty seconds can easily be got from an instrument which does not exceed I metre in height and length of boom. Prof. Alippi, in the Boll. Soc. Sismol. Ital., vol. x., No. 3 , describes a simple device for overcoming the tendency to adherence in the electric contacts of delicate seismoscopes; it consists in placing an ordinary electric bell, without the gong, in the circuit, and fixing it so that the clapper beats against the stone slab on which the seismoscope rests. He finds that the vibration set up by this is sufficient to cause the two parts of the contact to separate, without in any way affecting the instrument, and suggests that it would be better to incorporate a small electric vibrator in the base of the seismoscope to act like the decoherer in wireless telegraphy.

The mysterious sounds known locally as mist-poeffers, barisal guns, \&c., and now generally looked upon as seismic, are the subject of a short note by Prof. Alippi, who records two new localities and names. In the neighbourhood of Arezzo they are known as "baturlio della marina," and in the country between Bologna and Modena as "romba di Sassuolo." The multiplication of localities where these sounds are familiar, and of local names for them, is thought by Prof. Alippi to render a generic name desirable, and he suggests brontid, which has certainly the advantages of being descriptive and of implying no theory of origin ( $\mathrm{Bol}$. Soc. Sismol. Ital., x., part iii.).

The relation between the variations in latitude at Tokio and the occurrence of earthquakes in Japan is the subject of a paper by Prof. Omori in No. 18 of the Publications of the Earthquake Investigation Committee; he finds that the destructive earthquakes of the last eight years all occurred during periods of high or low value of the latitude, and none at times when this was changing from one to the other. This result is said to be in harmony with the results obtained by Prof. Milne, but we may point out that this is not so; what Prof. Milne found was that the greatest frequency of world-shaking earthquakes coincided with the most rapid variation in the position of the pole, while Prof. Omori finds that the destructive earthquakes of Japan occurred at times when the latitude was stationary or only changing very slowly. What his investigation seems to show is that any connection which there may be between the occurrence of really great earthquakes and changes in the position of the axis of revolution, does not extend to local earthquakes.

\section{UNIVERSITY AND EDUCATIONAL INTELLIGENCE.}

IN accordance with the will of the late Mr. George Smith, of St. Louis, the treasurer of Harvard University has received, it is stated by Science, a payment of $5^{1,500 l}$, When this funcl reaches $90,000 l$. by accumulation, three new dormitories are to be erected.

AT the institute of archæology of the University of Liverpool, a course of lectures dealing with recent researches on the ancient sites of Greece and with the historical geography of western Asia, particularly Palestine, has been arranged, and will be delivered on successive Wednesdays of this spring term. The lecturers are Dr. Caton and the Rev. M. Linton Smith.

THE President of the Board of Education has appointed Mr. T. S. Dymond, of the Essex County Technical Laboratories, Chelmsford, to an inspectorship under the Board, and to act as special adviser in matters of rural education, of nature-study in public elementary schools, of agricultural instruction in evening (including afternoon and Saturday) schools, and of the advancement of various forms of technical education in rural districts.

THE Bucks Education Committee, under the presidency of the chairman, Lord Buckinghamshire, has decided that a communication should be issued to all school corre- spondents in the county requesting the managers to consider the desirability of introducing the teaching of the subjects of hygiene and temperance into the schools under their charge, and referring to the support given to the movement by 15,000 members of the medical profession.

ABour twenty scholarships ranging in value from $20 l$. to 5ol. a year, and exhibitions for men and women tenable at University College, King's College, and the East London 'Technical College, in the faculties of arts, science, and engineering, will be offered for competition on June 27 and following days. Full particulars and forms of application may be obtained on application to the secretary of the Inter-Collegiate Scholarships' Board, King's College, Strand, W.C.

THE conference on school hygiene, which will be held at the University of London on February $7-10$, will be opened with an address by Sir Arthur W. Rucker, F.R.S., on "The Coordination of the Teaching of Hygiene." The subjects of papers for discussion include the following :-" "Physical and Mental Development during School Life," Miss A. J. Cooper; "Physical Inspection," Dr. A. K. Chalmers; "Building and Equipment," Sir Aston Webb, R.A.; "Sanitary Inspection," Dr. J. F. J. Sykes; "Training of Teachers," Prof. C. S. Sherrington, F.R.S.; and "Training of Scholars," Prof. Findlay.

THE British Medical Journal announces that the French Congress of School Hygiene will hold its second meeting in Paris this year at Whitsuntide. The following is the programme of discussions:-(I) the medical inspection of primary schools; (2) the education of families in school hygiene; (3) vacations and holidays; (4) tuberculosis and teachers; (5) the overloading of school courses and competitions for admission to large schools. Profs. Debove, Grancher, Landouzy, and Pinard are honorary presidents of the congress. All communications should be addressed to Dr. I. Ch. Roux, 46 rue de Grenelle, Paris.

THE annual general meeting of the Association of Technical Institutions is to be held at the Manchester School of Technology on January 27. The business will include the address of the president, Sir Philip Magnus, consideration of the council's report, the election of officers, and the reading of papers. The subjects to be dealt with are:- " The Coordination of the Work of Evening Continuation Schools and Municipal Technical Institutions," "The Cooperation of Employers in the Technical Training of their Apprentices," and "The Registration of Teachers in Technical Institutions."

THE annual general meeting of the members of the Association of Directors and Secretaries for Education was held in London on January 19 and 20. Mr. F. Wilkinson, the chairman for the year, presided, and in the course of his remarks dealt with the new regulations for secondary schools of the Board of Education. The following resolution was adopted by the association :"That the policy at present pursued at South Kensington with reference to the erection, financing, and control of secondary day schools is calculated to cast a heavy burden upon the ratepayers, while at the same time depriving them of adequate control."

Mr. A. J. Gimson described before the Institution of Mechanical Engineers on January 20 his impressions of sixteen engineering workshops visited by him in America. In the course of his remarks, he said that a feature of the engineering industry that impressed him was "the close intercommunication of technical institutes and manufacturing workshops, of professors and manufacturers, and the presence, in minor positions of authority, of young men who had passed through a complete course of technical instruction." In this country, manufacturers as a rule have yet to learn the value of scientific investigation and scientific education as factors of industrial progress.

Sir William White delivered an address at the Battersea Polytechnic on January $2 \mathrm{r}$ on the systematic study of 